\title{
Recommendations for teaching in a distributed learning environment: The students' perspective
}

\author{
Geraldine Lefoe \\ University of Wollongong \\ Cathy Gunn \\ University of Auckland \\ John Hedberg \\ University of Wollongong
}

\begin{abstract}
The University of Wollongong opened a new campus and two new access centres on the south coast of NSW, Australia, in 2000. The combination of distance with limited funding, after seed funding was expended, has provided opportunities to rethink teaching and learning strategies. Competition from traditional distance education providers in the area meant that, strategically, Wollongong had to "think differently". This paper provides an overview of issues identified by students through an evaluation of the inaugural year of a flexibly delivered Arts degree in a distributed learning environment. Actions taken by the University to resolve the issues are outlined and recommendations for implementation from the students' perspective are proposed.
\end{abstract}

\section{Introduction}

In Australia and New Zealand, the majority of universities are involved in some form of flexible or distributed learning, unfortunately without the major funding initiatives that are evidenced in Europe, Canada and US (Collis and De Boer, 1999; Sorg et al, 1999; Taylor 1996). Major evaluative research of these initiatives is not well reported in the literature and is often confidential to the institution. However there are many valuable, smaller studies which give insight into the changes occurring in these institutions (e.g. Chalmers, 1999; Gosper 1998; Gunn, 2001; Hedberg and CorrentAgostinho, 2000; Kirkwood and Ross, 1997; Taylor, 1999). Many universities have set up national and international satellite campuses to broaden their student base through provision of better access to education (Cunningham et al, 2000; Davidson, 1994). The University of Wollongong has followed this path. It is a regional institution, located on the South Coast of NSW, Australia, which has expanded to include a centre in Sydney and an international campus in Dubai. In 2000, further expansion 
took place when two new access centres (at Bega and Batemans Bay) and the Shoalhaven Campus opened their doors to students.

There are many guidelines and strategies identified to support teaching and learning in specific environments such as traditional on campus (Chickering and Gamson, 1987; Laurillard, 1993; Ramsden, 1992) distance education (Hill, 2001; Innovations in Distance Education Faculty, 1998,) or technology based environments (Chickering and Ehrmann, 1996). However there is a gap in the educational research literature when the convergence of distance and traditional on campus education occurs, as it does in a distributed learning environment (DLE). The aim of this study is to identify guidelines for teaching and learning to inform future subject development for this DLE. This paper focuses specifically on the student perceptions of the implementation year; reports on the actions by the stakeholders in response to issues identified and makes recommendations for future implementation and subject design in this DLE. It is part of a larger study, which looks at all aspects of the implementation of this Arts degree. Whilst the findings can not be generalised to other institutions, they provide direction for future research in the area.

\section{Background}

The focus of this case study research is the first year of implementation on the South Coast of an interdisciplinary Bachelor of Arts (Community and Environment). This new degree, developed over four years, is one of several degrees the University of Wollongong offers to students studying in the new locations. The degree has been designed to utilise a flexible learning approach within this distributed learning environment. Lecturers for the subjects were based at the Wollongong campus and local tutors were located at each of the centres. Students were required to attend tutorial sessions either once per week or once per fortnight for each subject and learning was supported through various technologies such as print, web or video content provision. Communication was supported through such things as video conferencing and web based discussion (Lefoe, Albury, Littler, and Trivett, 2001).

\section{Methodology}

The case study design has been chosen for this naturalistic evaluation to gather an in depth understanding of the implementation of the degree and to gain insight from those involved in this implementation (Guba and Lincoln, 1981; Hébert, 1986; Stake, 1995). The focus of the study is on the process of the implementation rather than on specific outcomes such as student results or satisfaction. It examines the whole context rather than a 
specific variable and seeks to discover rather than confirm existing hypotheses (Merriam, 1998). The main purpose of this case study was to identify how the first year was experienced by the primary stakeholders (students, tutors and lecturers) in order to describe the experience of teaching and learning in this new learning environment. This aspect of the study examined processes, through the eyes of the student, at the institutional, faculty and individual centre levels that supported the implementation, in order to improve these processes for further subject development of the degree and future iterations of the current subjects.

An overview of issues from the preliminary analysis of the data focused on the student perspective of teaching and learning. Students were interviewed through focus groups and semi-structured interviews on two occasions during the implementation year, with two to six participants in each group. This contributed to a "rich, thick description" of the case, which combined with member checks of the summary, provided verification for the method used (Creswell, 1998, p203). Although lecturers and tutors were also interviewed, the focus of this paper is on the student perceptions of implementation issues in their first year. Whilst the authors acknowledge the limitations of the small sample involved, the study may inform future research in the area.

\section{Student profile}

There were a total of 29 students enrolled in Bachelor of Arts across the three campuses, including part time and full time students, with an age range from 19 to 60 . The students at Shoalhaven Campus were predominantly post-secondary whilst at both of the other centres, they were predominantly mature age students. Since this was the inaugural year for the degree there was much discussion amongst the developers about what the student profile would look like. An earlier report (University of Wollongong, 1996) had indicated that few post secondary students interviewed indicated they would be attending a local campus as their preference was to leave home. Consequently the subjects were developed with the view that the majority of students would be mature age. An assumption was made from this report that these students would be highly motivated and self directed. For many of the post secondary students, self direction and motivation may have been a problem (McInnis, James and Hartley, 2000).

\section{Emerging issues in focus for evaluation}

From a preliminary analysis of the interview data, several key issues were identified as having significant impact on students in their first year. The researcher provided feedback to stakeholders as issues were identified so that action could be undertaken to resolve them. Whilst some of the issues 
were addressed, a report to stakeholders was held in October to identify further actions for resolving outstanding issues (Lefoe, 2000). Whilst it is recognised that many of the issues could be described as logistical in nature, the major themes have been identified as pedagogical, technological, learning support and administrative issues. Whilst many issues have aspects which overlap, it is recognised that all have some impact on student learning. The main themes and categories were identified during data analysis using NVivo software (Stake, 1995; Creswell, 1998). The examples are representative of the themes and categories raised by the students in the focus groups.

Table 1: Pedagogical issues and solutions

\begin{tabular}{|c|c|c|}
\hline $\begin{array}{l}\text { Pedagogical } \\
\text { issues }\end{array}$ & Students' comments & Action \\
\hline Workload & $\begin{array}{l}\text { I really didn't expect the workload to be as } \\
\text { heavy as what it is for four subjects. (BB } \\
\text { student). } \\
\text { It was an inhuman amount of work (BB } \\
\text { student). } \\
\text { Well, I'm unhappy, I don't have a life. I don't } \\
\text { go for a walk any more, I don't speak to my } \\
\text { children... (BB student) }\end{array}$ & $\begin{array}{l}\text { Ensure students are } \\
\text { aware of two hours } \\
\text { per credit point } \\
\text { time commitment. } \\
\text { Reduce enrolment } \\
\text { eg. full time to part } \\
\text { time }\end{array}$ \\
\hline Student role & $\begin{array}{l}\text { It's a different style of learning too, she's } \\
\text { incorporating, not a lot of academic jargon } \\
\text { going on, mostly chitchat and learning through } \\
\text { discussion. (Bega student) }\end{array}$ & $\begin{array}{l}\text { Clearly identify } \\
\text { changes to student } \\
\text { role in orientation. }\end{array}$ \\
\hline $\begin{array}{l}\text { Academic } \\
\text { role }\end{array}$ & $\begin{array}{l}\text { Students often interchanged the terms tutor } \\
\text { and lecturer in the discussion and many were } \\
\text { unaware of the role of the Dean, Sub-Dean and } \\
\text { Associate Dean. }\end{array}$ & Clarify roles. \\
\hline $\begin{array}{l}\text { Learning } \\
\text { community }\end{array}$ & $\begin{array}{l}\text { I must say that (Centre Coordinator's) } \\
\text { encouragement, when I rang up, ...she sort of } \\
\text { said 'Look yeah, I know it's hard. Don't give } \\
\text { up. Don't give up'. Because I was thinking I } \\
\text { could just bail out now before I fail, and so } \\
\text { that, yeah...her support's great. (Bega student). } \\
\text { That's another thing - time to spend with your } \\
\text { teachers and discuss your work. We've had a } \\
\text { couple of opportunities and I've found them to } \\
\text { be really important and useful (BB student). } \\
\text { I guess if you're on campus you can go knock } \\
\text { on the door and say 'I don't get this idea can } \\
\text { you explain it?' (Bega student). } \\
\text { The other thing that kept us going was the fact } \\
\text { that everyone else was saying the same so we } \\
\text { didn't feel like such a freak (BB student). }\end{array}$ & $\begin{array}{l}\text { Student support } \\
\text { provided through } \\
\text { coordinators, peer } \\
\text { support. } \\
\text { Informal } \\
\text { communication } \\
\text { with lecturers and } \\
\text { other students } \\
\text { through video } \\
\text { conferencing/ } \\
\text { email/ discussion } \\
\text { space }\end{array}$ \\
\hline
\end{tabular}




\section{Pedagogical issues and solutions (Table 1)}

In an on campus learning environment students may also identify these issues as problematic. However location meant it was more difficult for students to find answers to their problems, especially when they didn't know whom to contact.

At the individual subject level, the lecturers reviewed and adapted some parts of the subjects as a result of the feedback. The workload across the subjects was reviewed and one subject changed both the type and timing of the assessment tasks, incorporating some skill development in such things as essay writing.

Students may have been overwhelmed by the information they received at orientation about roles and expectations. A faculty handbook, "Studying on the South Coast", was produced to overcome some of these initial student problems. It identified student and staff roles in this learning environment; provided information about accessing administration, subjects online, the library and introductory support for essay writing, using word processors and the coursework system. However there is an expectation there that they read the booklet, just as there is an expectation that students read subject outlines.

Communication with lecturers who were based at Wollongong was identified as a difficulty but perhaps no more so than on campus where "knocking on their door" is also restricted by availability of the lecturers for a variety of reasons including their increased workload. However, faculty-student interaction is identified as an important component of student learning (Kuh and $\mathrm{Hu}, 2001$ ) and can be addressed through the effective use of available technologies such as email and discussion spaces or making a specific time available for these students to phone them.

The building of a learning community, where all members feel they belong and their contributions are valued, is also clearly important. Campus coordinators were an integral part of this development, as were the tutors and the students themselves, supporting each other with their learning. The development and support of a learning community, which expands to include members from other centres and lecturers in Wollongong, are essential to the success of this venture. Maximising the use of technology to support this development is a key to ensuring success.

\section{Technological issues and solutions (Table 2)}

Technology issues were a major focus for students in the discussion and varied from centre to centre. The majority of students at the Shoalhaven Campus indicated that computer training was not an issue for them as most felt that they were comfortable using the technology. Most of these students also lived within a reasonable distance to the campus though 
access to campus laboratories out of hours was an issue for them. Many of the students at Batemans Bay had access to computers at home and work and those who did not had extended access out of hours at the centre. Students in Bega indicated that most did not have computer access at home, in fact some had no electricity. Many had limited previous experience and for some, distance to the centre (up to 2 hours driving time) was an issue. Local Bega students used the 24 hour access at the centre.

Students were critical of how technology was applied in some of their subjects and were able to identify where it was used well (Table 2 discussion space). The choice of appropriate technology in subject design is an important component in any curriculum. Video and audio recordings of Wollongong lectures were not produced professionally so the students found it difficult to focus on the content and frequently didn't use them. This was the response by some subject developers to reproduce a traditional learning environment because they did not come to terms with changing the teaching and learning strategies used in this new environment.

\section{Learning support issues and solutions}

For students in this new learning environment, learning support was essential (Table 3). Many were mature age students, who had not engaged in formal learning and its requirements for some time.

Support for student learning is identified in much of the literature as critical for effective teaching in any learning environment (Chalmers and Fuller, 1996; Prosser and Trigwell, 1999). The need for flexible access to resources and learning support is even more imperative in a distributed learning environment (Chalmers, 1999; Fowler and Branch, 2000).

At the University of Wollongong, learning support for students is provided through academic staff in Learning Development. For this new degree learning support was initially provided through face to face workshops on such things as essay writing skills, which many students did not attend because of timetable conflicts or other commitments. This kind of support is now provided though a WebCT site specifically providing generic skill development in such things as essay writing. The provision of access to online support will mean that students can use materials when they require assistance.

Future offerings of a core compulsory subject with embedded learning support will ensure that all students develop the skills required. This approach provides all students with assistance in making the transition to tertiary and discipline based studies in an innovative and systemic approach to learning support (Skillen et al, 1999). 
Table 2: Technological issues and solutions

\begin{tabular}{|c|c|c|}
\hline $\begin{array}{l}\text { Technological } \\
\text { issues }\end{array}$ & Students' comments & Action \\
\hline $\begin{array}{l}\text { Computer } \\
\text { access }\end{array}$ & $\begin{array}{l}\text { It mightn't seem like much to ring her but when } \\
\text { you're ringing long distance it is, and when you } \\
\text { haven't got access to a computer, to email or } \\
\text { anything, from Eden to Bega it's long distance. } \\
\text { (Bega student) } \\
\text { Student } 1 \text { : And the web based stuff, I think my } \\
\text { problem with it is having to download (and } \\
\text { print)... because it's ten cents a page, if you don't } \\
\text { have a computer, you can't leave it on there. } \\
\text { Student 2: I found it a lot easier with the book } \\
\text { last time...just give us the book (Bega student). }\end{array}$ & $\begin{array}{l}\text { Extended access } \\
\text { to computer labs } \\
\text { out of hours. } \\
\text { Provision of clear } \\
\text { guidelines for } \\
\text { assessment tasks } \\
\text { and marking } \\
\text { criteria. } \\
\text { Provide hard copy } \\
\text { of subject material } \\
\text { when appropriate. }\end{array}$ \\
\hline Training & $\begin{array}{l}\text {...Things like using databases - I've just started } \\
\text { to scratch the surface now and it would have } \\
\text { been really good had I had those skills earlier. } \\
\text { (Batemans Bay (BB) student) } \\
\text { I was impressed that I could learn it off the } \\
\text { screen. (BB student) }\end{array}$ & $\begin{array}{l}\text { Include skill } \\
\text { workshops in } \\
\text { orientation } \\
\text { activities plus } \\
\text { online training } \\
\text { resources like the } \\
\text { Database tutorial }\end{array}$ \\
\hline $\begin{array}{l}\text { Trouble } \\
\text { shooting }\end{array}$ & $\begin{array}{l}\text {...Very often just when you really need this } \\
\text { technology it just doesn't happen to be } \\
\text { working... (BB student) } \\
\text { It's really frustrating especially when you go in } \\
\text { to print something. (Bega student) } \\
\text { I love (the computer) at home now because my } \\
\text { kids turn to me to fix things, whereas they } \\
\text { taught me how to turn it on and get it going... } \\
\text { six months ago I was almost computer illiterate, } \\
\text { and now I'm the one that fixes everything on the } \\
\text { computer. It's so cool. I love it. (BB student) }\end{array}$ & $\begin{array}{l}\text { Monitor } \\
\text { equipment } \\
\text { performance; } \\
\text { provide checklists } \\
\text { for problem } \\
\text { solving with } \\
\text { equipment; } \\
\text { further training } \\
\text { for students; } \\
\text { encourage peer } \\
\text { support. }\end{array}$ \\
\hline $\begin{array}{l}\text { Appropriate } \\
\text { use } \\
\text { a) use of } \\
\text { asynchronous } \\
\text { discussion } \\
\text { space }\end{array}$ & $\begin{array}{l}\text { Student 1: The one good thing about the Arts } \\
\text { subject was the bulletin board because it was } \\
\text { compulsory to do it - to put } 2 \text { postings on per } \\
\text { module and a module went for } 3 \text { weeks. And so } \\
\text { in that way the bulletin board really got a good } \\
\text { use } \\
\text { Student 2: It made you really read what you had } \\
\text { to read, you didn't want to just put something } \\
\text { really wishy washy on there and everyone else } \\
\text { is going to read it and go from that you wanted } \\
\text { to put something really substantial on there. } \\
\text { Student 1: That's right. At the same stage in } \\
\text { some of the subjects in the early semester, } \\
\text { without having a reason to be on the bulletin } \\
\text { board it's just died. (Shoalhaven students) }\end{array}$ & $\begin{array}{l}\text { Set clear } \\
\text { expectations in } \\
\text { assignments. } \\
\text { Provide a clear } \\
\text { purpose for } \\
\text { students to use } \\
\text { the discussion } \\
\text { space. }\end{array}$ \\
\hline
\end{tabular}




\begin{tabular}{|l|l|l|}
\hline $\begin{array}{l}\text { Appropriate } \\
\text { use } \\
\text { b) video } \\
\text { conferencing }\end{array}$ & $\begin{array}{l}\text { I hate that audiovisual thing that's completing } \\
\text { alienating. (Bega student) } \\
\text { Someone would say something off the top of } \\
\text { their head and someone would say we couldn't } \\
\text { hear that. You would have to get the speaker } \\
\text { and put it closer to them and so (they would) } \\
\text { want you to repeat it. You'd like, oh you know, } \\
\text { it did make it a bit just a little bit different. } \\
\text { (Shoalhaven student) } \\
\text { By the end I think you were just - you know } \\
\text { they are there and it didn't really matter. } \\
\text { (Shoalhaven student) }\end{array}$ & $\begin{array}{l}\text { training for using } \\
\text { conferencing } \\
\text { during } \\
\text { orientation; } \\
\text { increase training } \\
\text { to ensure } \\
\text { pedagogically } \\
\text { sound methods } \\
\text { used. Increase } \\
\text { number of } \\
\text { microphones at } \\
\text { each campus. }\end{array}$ \\
\hline $\begin{array}{l}\text { Appropriate } \\
\text { use c) } \\
\text { video/audio } \\
\text { lectures }\end{array}$ & $\begin{array}{l}\text { The tapes are great ... even in the other subjects } \\
\text { they have tapes. (BB student) } \\
\text { I actually find the lectures a bit useless - I have } \\
\text { to say. And it's partly just because of the } \\
\text { technology. The videotapes are often really, } \\
\text { really hard to decipher and to hear what's going } \\
\text { on... (Bega student) }\end{array}$ & $\begin{array}{l}\text { Ensure high } \\
\text { quality recordings } \\
\text { through use of } \\
\text { campus recording } \\
\text { facilities. }\end{array}$ \\
\hline
\end{tabular}

The careers counseling service initiated visits to the centres followed by video conferencing with students as required. This service also provided access to online materials, and individual communication through email and phone. The decision by the library to initiate an electronic reserve collection meant increased access to resources for these students. Whilst the Shoalhaven students had access to their own library it was new and had limited resources. The Bega and Batemans Bay centres had their small collection stored at the local regional library and access was limited not only by the small number of resources but also the opening hours. The electronic reserve collection meant that lecturers could provide readings, including single chapters of books to provide a much wider and up to date resource base for their students (Lefoe, 2001).

Visits to the centres by the Dean and Associate Dean to give academic advice provided visible support for students (and tutors) and modelled a practice of occasional centre visits which they were encouraging teaching staff to follow. It also highlighted the importance they placed on the success of the centres.

\section{Administrative issues and solutions}

Administrative issues (Table 4) were a major stumbling block for students at a distance from the main campus. Whilst espoused administrative and pedagogical practice at the Wollongong campus appeared to work well, the actual practices, when used in distributed environments, did not. New knowledge, understandings and procedures are required for such 
initiatives and the tacit knowledge of those in Wollongong of how the system worked was not readily available to those in the new centres. A lack of email access prevented some students from accessing key learning materials in the first week of session at a time when new students are nervous about their ability to learn in a new environment. A new administrative system, that provided students with control and easy access to information about their enrolment, simplified the process.

Table 3: Learning support issues and solutions

\begin{tabular}{|c|c|c|}
\hline $\begin{array}{c}\text { Support } \\
\text { issues }\end{array}$ & Students' comments & Action \\
\hline $\begin{array}{l}\text { Student } \\
\text { support }\end{array}$ & $\begin{array}{l}\text { If someone could come and talk to us, if there } \\
\text { was an adviser that we could talk to about it, } \\
\text { computer problems, stress, big workload, } \\
\text { maybe we could pop in a mini-bus and head } \\
\text { up to Wollongong. (BB student) }\end{array}$ & $\begin{array}{l}\text { Provide support } \\
\text { through visits to } \\
\text { centres, email, and } \\
\text { video conferencing. }\end{array}$ \\
\hline $\begin{array}{l}\text { Access to } \\
\text { resources }\end{array}$ & $\begin{array}{l}\text { When books are on reserve you can only sort } \\
\text { of have them overnight ... I'm only } 30 \mathrm{~km} \\
\text { away but other people are about 50-60. (Bega } \\
\text { student) }\end{array}$ & $\begin{array}{l}\text { Electronic reserve } \\
\text { initiative } \\
\text { implemented plus } \\
\text { increased online } \\
\text { journal access. } \\
\text { Library processes } \\
\text { reviewed to extend } \\
\text { reserve loans. }\end{array}$ \\
\hline $\begin{array}{l}\text { Career } \\
\text { counselling }\end{array}$ & $\begin{array}{l}\text { (I'd like to see) a careers person so you could } \\
\text { sort of sit down and say well you know, if I do } \\
\text { this where's this going to take me. (Bega } \\
\text { student) }\end{array}$ & $\begin{array}{l}\text { Provide support } \\
\text { through visits to } \\
\text { centres, email, and } \\
\text { video conferencing. }\end{array}$ \\
\hline $\begin{array}{l}\text { Learning } \\
\text { support }\end{array}$ & $\begin{array}{l}\text { It was quite good; it could have been better if it } \\
\text { was scheduled (to meet our timetable). (BB } \\
\text { student). } \\
\text { He came down the day he had a big test - one } \\
\text { for English on a Tuesday (Beg a student). }\end{array}$ & $\begin{array}{l}\text { Online and paper } \\
\text { based learning } \\
\text { support materials } \\
\text { provided. Learning } \\
\text { support embedded in } \\
100 \text { level subjects. }\end{array}$ \\
\hline $\begin{array}{l}\text { Academic } \\
\text { advice }\end{array}$ & $\begin{array}{l}\text { That would have been a good point to give to } \\
\text { us at the start of it, like the start of } 1^{\text {st }} \text { semester, } \\
\text { just say look, these...these subjects that you'll } \\
\text { be covering this year are very broad, just sort } \\
\text { of like an introduction (Shoalhaven student) }\end{array}$ & $\begin{array}{l}\text { Provide support } \\
\text { through visits to } \\
\text { centres, email, and } \\
\text { video conferencing. }\end{array}$ \\
\hline
\end{tabular}

The University of Wollongong now has in place an online student management system which allows students to enrol, set up email and internet access, change subjects and personal details, access results, as well as a student inquiry centre. 
Table 4: Administrative issues and solutions

\begin{tabular}{|c|c|c|}
\hline $\begin{array}{c}\text { Administrative } \\
\text { issues }\end{array}$ & Students' comments & Action \\
\hline $\begin{array}{l}\text { Enrolment, } \\
\text { subject } \\
\text { changes, } \\
\text { timetable } \\
\text { changes }\end{array}$ & $\begin{array}{l}\text { Many students commented in first few } \\
\text { weeks about difficulties with these issues. } \\
\text { (The timetable) was totally changed, it was } \\
\text { totally different. (Shoalhaven student). } \\
\text { It's a pretty big issue for us because I'm } \\
\text { trying to work and support myself at the } \\
\text { same time (Shoalhaven student). }\end{array}$ & $\begin{array}{l}\text { Student Online } \\
\text { system (SOLS) } \\
\text { introduced and } \\
\text { updated to allow } \\
\text { students to make } \\
\text { changes as required } \\
\text { and to access up to } \\
\text { date information. }\end{array}$ \\
\hline $\begin{array}{l}\text { Email } \\
\text { accounts }\end{array}$ & $\begin{array}{l}\text { First semester there were troubles with the } \\
\text { bar codes, log on. Took us about } 2 \text { weeks. } \\
\text { So that (was) really frustrating trying to } \\
\text { work it out. And getting their account } \\
\text { numbers and all this nonsense. That was a } \\
\text { real shemozzle. They didn't work. } \\
\text { (Shoalhaven students). }\end{array}$ & $\begin{array}{l}\text { Online initiation } \\
\text { system introduced } \\
\text { Generic accounts } \\
\text { established for } \\
\text { subject access when } \\
\text { email problems arise. }\end{array}$ \\
\hline
\end{tabular}

\section{Recommendations for teaching in a distributed learning environment}

Chickering and Gamson, (1987) provided some indicators for faculty of ways in which they can improve the learning experience for their students in on campus environments. They include student-faculty interaction, peer interaction and cooperation, active learning, feedback, time on task, high expectations and respect for diversity and learning styles (Chickering and Gamson, 1987) p1. These principles were adapted in later work (Chickering and Ehrmann, 1996) which focused upon "cost effective and appropriate ways" to use technology to advance these principles. While Chickering, Gamson and Ehrmann derived their principles from a teaching perspective, issues identified by students in this study both support those principles but also suggest that they need to be refocused from the learner's perspective. Especially with administration and learning support concerns, which may not be seen as impacting on student learning so critically when it is on campus. Moreover in a distributed learning context these issues become impediments for the students as the lecturers are often unaware of these administrative and learning support concerns.

Thus issues identified by students extend the previous principles and provide the basis for learner focused guidelines for subject design and implementation in a distributed learning environment.

\section{Set me clear role expectations}

Students indicated a need for a clear idea of time commitment required for each subject and reasonable workloads. Many students are working part 
time or full time and have family or other commitments. A recent study by Kember (1998) examined students' perceptions of workload. Where students perceive their workload as overly high it can lead to a reduction in class enrolments and has a negative effect on their learning. Although they point out that actual workload is difficult to measure with any precision, their research identified that when workloads are perceived as high by students they tend to resort to a surface approach to learning, that is they rote learn material. The converse was also true that when students rote learn material or use a surface approach to learning, they perceive their workload as high (Entwistle and Ramsden, 1983, Marton and Booth, 1997).

In a student centred learning environment they also require an understanding of the changed role of students and their lecturers (Biggs, 1999; Ramsden, 1992). If students are to take more responsibility for their learning, as they are required to do in a distributed learning environment, then clear expectations must be set for all facets of their learning. They will require scaffolding to move from the beliefs they may already hold about learning, to thinking differently about their role as a student and the discipline and approach to study that this may require.

When an online component is incorporated in the learning environment, then students need to develop new strategies to develop skills and to manage their learning. Tutors and lecturers can provide guidance in this area so students set realistic goals and understand how each person's role contributes to achieving the outcomes (See Gunn, 2001).

\section{Talk to me}

Although students had face to face contact with local tutors they also indicated that contact with the lecturer or subject coordinator was important to them. This could be supported through various communication technologies and when used asynchronously provide opportunity for students and faculty to respond at a time which is convenient to them (Pascarella and Terenzini, 1998; Kuh, 2001). Student satisfaction and development generally improves as the amount of contact they have inside and outside the classroom increases (Astin, 1993). Laurillard's conversational model also suggests that students need feedback on the concepts they are learning (Laurillard, 1993). Although the tutors were providing this to some extent, interaction with the lecturer could also provide this feedback, though it could also be provided to some extent through automatic feedback in web based self testing, since prompt feedback is not always possible in a distributed learning environment.

\section{Provide opportunity to work and talk with other students}

Contact with students from other centres is also important to them when 
they are small isolated groups but even at the larger centre the students indicated that group work provided opportunity to get to know other students and facilitated a feeling of belonging to a community (Gabelnick, 1990). Collaborative and cooperative activities are highlighted in the Seven Principles as increasing students' involvement in their learning (Chickering and Gamson, 1987). Information and communication technologies can support such activities as group work, study groups, and discussion of assignments when the students are separated by location.

\section{Choose the best medium for the task at hand}

The choice of the best medium for the task is essential as well as ensuring that high quality resources are developed that meet the learning needs of students. Earlier research focused on the impact of different media used to transmit information rather than the nature of relationships or the nature of interactions or indeed the quality of the resources (Seels, Berry, Fullerton and Horn, 1996). Clark (1983) initiated a debate in his landmark paper that questioned the current research on conditions under which media influenced learning. He stated that 'media... are mere vehicles that deliver instruction but do not influence student achievement any more than the truck which delivers our groceries causes changes to our nutrition" (Clark, 1983). This issue continued to be debated in 1994 (see Kozma, 1994) with a special issue of Educational Technology Research and Design and is still provoking debate today about whether researchers are asking the right questions (Ehrmann, 1997).

Determining the most appropriate technology to support learning can be a time consuming task for lecturers and students. When audio and videotapes are used, it is best if high quality recordings are made if students are to make use of them. However time constraints and accessibility to resources to create the high quality solution can limit the choice of medium.

\section{Teach me to use the technology}

Although some training was provided for students in orientation week they indicated that they need flexible access to training. There is an expectation that many students have developed IT skills during high school, for example many of the Shoalhaven students, however, the mature age students may not have used computers at all (Candy et al 1994). Moran (1995) identified that students require "support and training ... in accessing and learning how to use ITs in the context of their study" (Moran, 1995 p16). Barrakeet (2000) also identified from the literature that:

productive use of CIT by students is achieved through the interaction of convenient and reliable access to 'front end' infrastructure, appropriate use (both by the student and the academic) of CIT which is part of a broader learning design, and reasonable support for this use by the staff, systems, infrastructure and processes of the University. pxiii. 
Training students to use technology could be embedded in subjects to ensure that students develop the skills, as they are required. Computer based training packages and support will allow flexible access to meet student needs.

\section{Provide resources I can use}

Creating new library systems can be a challenge, not only within the university but also for creating partnerships with local town libraries providing students with access to information resources (McPherson et al, 1997). In one centre the local library had not yet moved to an electronic catalogue system and this not only limited borrowing for students but also restricted the support they were able to provide students in accessing materials available electronically (Fowell, 1995). The students at the other centres were extremely positive about the library access but needed further skill development in using databases and electronic resources. Access to library and other resources can be extremely limited in isolated areas. Efficient and effective systems that support these students can be provided through access to full text databases and electronic journals together with flexible borrowing systems (Lefoe et al, 2001).

\section{Let me know what support is available}

As the student profile has changed significantly in higher education in Australia since 1988 and the move to a mass education system, support services have been identified as critical to enrolment attrition (Promnitz and Germain, 1996). On campus student support services are often well developed but may be difficult for non-local students to access or may simply not be used. Integrating learning support within subjects improves the skills of all students (Skillen et al, 1999). Visits to more isolated centres or the use of technology such as video conferencing can be used for individual meetings with other services such as career development and counselling services. A student handbook which lists all support services and how to access them is also worthwhile.

\section{Guide me through the administrative nightmare}

Administration difficulties for on campus students can be challenging, when they are removed from the campus the frustration levels are even higher. Administration should not be a nightmare if systems are in place to support students. An online administration system that provides access for students to review and change their subjects, access timetables, and initiate their email accounts can simplify this process. The report, An Emerging Set of Guiding Principles and Practices for the Design and Development of Distance Education, suggests that students at a distance should have administration access that is at least as good as that available on campus. We would suggest that they deserve a better system. A helpdesk facility is also essential to support remote students (Innovations in Distance Education Faculty, 1998). 


\section{Conclusion}

The inaugural year of any new degree is a challenge for students and staff alike. In a distributed learning environment the challenge is greater, particularly when everyone at the local sites is also new to the institution and how its systems work. The issues identified here don't portray the many successes achieved in this first year, or the hard work of all those involved in making this innovation a success. Nor do they portray the enthusiasm and dedication of the students to overcome the challenges they faced.

The University of Wollongong has used the lessons learnt from this implementation to develop more flexible teaching and learning practices at the Wollongong campus, the Dubai campus, and at international locations where the University currently has partnerships with other institutions. Whilst the current case study cannot be generalised to these other contexts, ensuring the key issues are resolved provides opportunity to target other issues in teaching and learning for all students at the University of Wollongong.

Despite the early implementation issues, it is appropriate that the final words come from the students:

- I just think that it's a fantastic opportunity here, to be able to learn, it's just amazing.

- Yeah, it's great. I love it too. We're very lucky really; we've got it good.

- And we've got really good tutors; we've got a really good course.

\section{References}

Albury, R. (2001). On being 'Head' - Reflections on leading an educational innovation involving computer technology. In G. Kennedy, M. Keppell, C. McNaught \& T. Petrovic (Eds), Meeting at the Crossroads. Proceedings of the 18th Annual Conference of ASCILITE, Melbourne. (pp.23-29).

Astin, A. W. (1993). What Matters in College: Four Critical Years Revisited. San Francisco: Jossey-Bass.

Barraket, J. and DETYA. (2000). Equity and the Use of Communications and Information Technology in Higher Education: A UTS Case Study. Canberra, ACT: EIP, Higher Education.

Biggs, J. (1999). Teaching for Quality Learning at University: What the Student Does. Buckingham: SRHE and Open University Press.

Candy, P. C., Crebert, G. \& O'Leary, J. (1994). Developing Lifelong Learners Through Undergraduate Education (Commissioned report 28). Canberra: NBEET \& AGPS.

Chalmers, D. (1999). A strategic university-wide initiative to introduce programs of study using flexible delivery methods. Interactive Learning Environments, 7(2-3), 249-268. 
Chalmers, D. and Fuller, R. (1996). Teaching for Learning at University: Theory and Practice. London: Kogan Page.

Chickering, A. \& Gamson, Z. (1987). Seven principles for good practice in undergraduate education. AAHE Bulletin (March), 3-6. http:/ / www.hcc.hawaii.edu/intranet/ committtees/FacDevCom/guidebk/teac htip/7princip.htm

Chickering, A. \& Ehrmann, S. (1996). Implementing the seven principles: Technology as lever. AAHE Bulletin (October), 3-6. http: / / www.tltgroup.org/erhmann.htm

Clark, R. (1983). Reconsidering research on learning from media. Review of Educational Research, 53(4), 445-459.

Collis, B. \& De Boer, W. (1999). Scaling up from the pioneers: The TeleTOP method at the University of Twente. Interactive Learning Environments, 7(2-3), 93-111.

Creswell, J. W. (1998). Qualitative inquiry and research design: choosing among five traditions. Thousand Oaks, Calif.: Sage Publications.

Cunningham, S., Ryan, Y., Stedman, L., Tapsall, S., Bagdon, K., Flew, T. \& Coaldrake, P. (2000). The Business of Borderless Education. Canberra: AGPS.

Davidson, G. R., Dekkers, J. \& Booth, C. (1994). Branch Campus Models in Australian Higher Education. Canberra: AGPS.

Ehrmann, S. (1997). Asking the right question: What does research tell us about technology and higher education. [24 Sep 2001] http: / / www.learner.org/edtech/rscheval/ rightquestion.html

Entwistle, N. J. \& Ramsden, P. (1983). Understanding Student Learning. London: Croom Helm.

Fowell, S. \& Levy, P. (1995). Developing a new professional practice: A model for networked learner support in higher education. Journal of Documentation, 51(3), 271-280.

Fowler, J. \& Branch, S. (2001). Supporting students and staff in a flexible learning environment: A case study. In L. Richardson and J. Lidstone (Eds), Flexible Learning for a Flexible Society, 273-280. Proceedings of ASET-HERDSA 2000 Conference, Toowoomba, Qld, 2-5 July 2000. ASET and HERDSA. http:/ / cleo.murdoch.edu.au/gen/ aset/ confs/ aset-herdsa2000/ procs/ fowler.html

Gabelnick, F., MacGregor, J., Matthews, R. S. \& Smith, B. L. (1990). Learning Communities: Creating Connections Among Students, Faculty and Disciplines. San Francisco: Jossey-Bass, Inc.

Gosper, M. \& Rich, D. (1998). Introducing flexibility into educational programs: The Macquarie University experience. Paper presented at the Edmedia/Ed-Telecom 98 World Conference on Educational Multimedia and Hypermedia, Frieberg, Germany.

Guba, E. G. \& Lincoln, Y. S. (1981). Effective evaluation. (1st ed.). San Francisco:Jossey-Bass

Gunn, C. (2001). Effective online teaching - how far do the frameworks go? In G. Kennedy, M. Keppell, C. McNaught \& T. Petrovic (Eds), Meeting at the Crossroads. Proc. of the 18th Annual Conf. of ASCILITE, Melbourne. 
Hébert, Y. (1986). Naturalistic evaluation in practice: A case study. In Williams, D.D. (Ed), Naturalistic Evaluation. San Francisco: Jossey-Bass.

Hedberg, J. \& Corrent-Agostinho, S. (2000). Creating a postgraduate virtual community: Assessment drives learning. Educational Media International, 37(2), 83-90.

Hill, J. R. (2001). Building community in web-based learning environments: Strategies and techniques. Proceedings Ausweb01 Conference, Coffs Harbour. http: / / ausweb.scu.edu.au/aw01/ papers / refereed/hill / paper.html

Innovations in Distance Education Faculty (1998). An Emerging Set of Guiding Principles and Practices for the Design and Development of Distance Education. The Pennsylvania State University. http: / / www.outreach.psu.edu/de/ide/

Kember, D. \& Leung, D. Y. P. (1998). Influences upon students' perceptions of workload. Educational Psychology, 18(3), 293-307.

Kirkwood, J. \& Ross, D. (1997). Multimedia design and development: An industry simulation project delivered on the Internet. In J. Osbourne, D. Roberts \& J. Walker (Eds), Open, Flexible and Distance Learning: Education and Training in the 21st Century, 13th Biennial Forum of ODLAA, pp.174-178

Kozma, R. (1994). A reply: Media and methods. Educational Technology, Research and Development, 42(3), 11-14.

Kuh, G. D. \& Hu, Shouping (2001). The effects of student-faculty interaction in the 1990s. The Review of Higher Education, 24(3), 309-332.

Laurillard, D. (1993). Rethinking University Teaching: A Framework for the Effective Use of Educational Technology: Open University Press.

Lefoe, G. (2000). Part B - Teaching and Learning Evaluation. In S. Wills, G. Lefoe \& R. Mobbs (Eds), The South Coast: Progress 2000 and Preparation 2001 (Unpublished report). Wollongong: University of Wollongong

Lefoe, G., Albury, R., Littler, C. \& Trivett, N. (2001). Collaborative partnerships: Changing roles for academic and support staff in new learning environments. In J. G. Hedberg (Ed), Online Learning Environments: Research and Teaching. RILE Monograph. Wollongong: Faculty of Education, University of Wollongong.

Mark, M. M. \& Shotland, R. Lance. (1987). Alternative modes for the use of multiple methods. In M. M. Mark \& R. L. Shotland (Eds), Multiple Methods in Program Evaluation: New Directions for Program Evaluation (pp. 95-100). San Francisco: Jossey-Bass.

Marton, F. \& Booth, S. (1997). Learning and Awareness. Mahwah, NJ: Erlbaum.

McInnis, C., James, R. \& Hartley, R. (2000). Trends in the First Year Experience in Australian Universities. Canberra: DETYA.

McPherson, M., Curry, D. \& Humphreys, J. (1997). Hervey Bay Library: A new joint-use public/university library service: Lessons for tomorrow. Paper presented at the Creating Tomorrow Today: Can you imagine... Proceedings of the 1997 Public Libraries Section and Reference and Information Service Section Conference, Brisbane.

Merriam, S. B. (1998). Qualitative Research and Case Study Applications in Education. San Francisco: Jossey-Bass. 
Moran, L. (1995). National Policy Frameworks to Support the Integration of Information Technologies into University Teaching/Learning: Canberra: DEET.

Pascarella, E. T. \& Terenzini , P. T. (1998). Studying college students in the 21st century: Meeting new challenges. The Review of Higher Education, 21(2), 151-165.

Promnitz, J. \& Germain, C. (1996). Student Support Services and Academic Outcomes: Achieving Positive Outcomes (96/10). Canberra: Evaluations and Investigations Program, Higher Education Division.

Prosser, M. \& Trigwell, K. (1999). Understanding Learning and Teaching. Buckingham: The Society for Research in Higher Education and OU Press.

Ramsden, P. (1992). Learning to Teach in Higher Education. London: Routledge.

Seels, B., Berry, L., Fullerton, H. \& Horn, K. (c1996). Research on learning from television. In D. H. Jonassen (Ed), Handbook of Research for Educational Communications and Technology: A Project of the Association for Educational Communications and Technology. New York: Macmillan Library Reference USA.

Skillen, J., Trivett, N., Merten, M. \& Percy, A. (1999,). Integrating the instruction of generic and discipline specific skills into the curriculum: a case study. Paper presented at the HERDSA Annual International Conference, Melbourne, 12-15 July. http: / / herdsa.org.au/vic/ cornerstones/

Sorg, S., Truman-Davis, B., Dziuban, C., Moskal, P., Hartman, J. \& Juge, F. (1999). Faculty development, learner support and evaluation in web-based programs. Interactive Learning Environments, 7(2-3), 137-153.

Stake, R. E. (1995). The Art of Case Study Research. Thousand Oaks: Sage.

Taylor, P. G., Lopez, L. \& Quadrelli, C. (1996). Flexibility, Technology and Academics' Practices: Tantalising Tales and Muddy Maps (EIP 96/16). Canberra: DEETYA.

Taylor, P. G. (1999). Making Sense of Academic Life: Academics, Universities and Change. Philadelphia, PA : Open University Press.

University of Wollongong. (1996). Submission to the Commonwealth/ State Working Party on Higher Education Provision on the South Coast of New South Wales. (Unpublished Report): University of Wollongong

Geraldine Lefoe, Centre for Educational Development and Interactive Resources, University of Wollongong, Australia. glefoe@uow.edu.au

Cathy Gunn, School of Education, University of Auckland, New Zealand ca.gunn@auckland.ac.nz

John Hedberg, Faculty of Education, University of Wollongong, Australia jhedberg@uow.edu.au

An earlier version of this article was published under:

Lefoe, G., Gunn, C. \& Hedberg, J. (2001). Recommendations for teaching in a distributed learning environment: The students' perspective. In G. Kennedy, M. Keppell, C. McNaught \& T. Petrovic (Eds), Meeting at the Crossroads. Proceedings of the 18th Annual Conference of the Australasian Society for Computers in Learning in Tertiary Education. (pp. 355-365). Melbourne: Biomedical Multimedia Unit, The University of Melbourne. http: / / www.medfac.unimelb.edu.au/Ascilite2001/pdf/ papers/lefoeg.pdf 